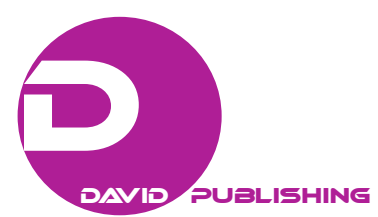

\title{
Study on the Economic Logic of "The Belt and Road" Initiative of China
}

\author{
CHEN Yongjun, LIU Yongfeng \\ Renmin University of China, Beijing, China
}

\begin{abstract}
“The Belt and Road” Initiative is one of the Chinese medium- and long-term national development strategies which are mainly to create a new driving force of economic growth and develop a new pattern of opening-up. Starting analyzing the background of international and domestic economy, "the Belt and Road" Initiative was put forward. This paper constructed the theoretical model of "the Belt and Road" in the abstract, and certified its inherent economic logic and provided a new perspective for understanding the economic nature of "the Belt and Road”. On this basis, this paper also analyzed the significance of "the Belt and Road” to China's development and how to cooperate between China and European countries and between China and the North American countries. The results show that "the Belt and Road" initiative is conducive to combine the advantages of capital and capacity of China and the advantage of market of Central and West Asian countries and Africa countries to achieve the multi-win situation, and European countries and North American countries can join this initiative deeply by taking advantages of their technologies and so on.
\end{abstract}

Keywords: the Belt and Road, development of economy, economic interaction, the supply and demand, regional economic integration, win-win situation

\section{Introduction}

Under the background in which the recovery of world economy is weak and monetary policies of developed economies are moved towards differentiation, many countries' economies are facing difficulties. It needs new economic growth points or a new economic locomotive to drive world economy. After judging and considering the situation carefully, China is trying its best to integrate almost all nations' strategies and policies into "the Belt and Road" and APEC to achieve a win-win situation.

From the perspective of domestic economy, since the reform and opening-up in 1978 and the comprehensive construction of market economy in 1992, China's economy showed a sustained and rapid growth trend which was rare in the economic history. Behind this, the effects of three driving forces (investment, consumption, and net export) are self-evident: on the one hand, the investment facilitates capital

This paper is supported by the Key Research Institute of Humanities and Social Science in University of Ministry of Education of the People's Republic of China, No. 16JJD790059.

CHEN Yongjun, Ph.D. in Economics, professor, Business School of Renmin University of China, Beijing, China.

LIU Yongfeng, doctor candidate in Economics, Business School of Renmin University of China, Beijing, China.

Correspondence concerning this article should be addressed to CHEN Yongjun, Business School of Renmin University of China, No. 59, Zhongguancun Street, Haidian District, Beijing, 100872, China. 
accumulation and then promotes economic growth from the supply side ${ }^{1}$; on the other hand, consumption and net export facilitate domestic and external demand, and thus stimulate economic growth from the demand side. And now, "the Belt and Road" construction will not only promote the growth of investment directly (especially in the infrastructure sector ${ }^{2}$ ), but also contribute to the trade development indirectly.

“The Belt and Road” is short for the Silk Road Economic Belt and the 21st-century Maritime Silk Road. The key directions of the Silk Road Economic Belt are from China, via Central Asia and Russia, to Europe (the Baltic Sea); from China, via Central Asia and West Asia, to the Persian Gulf and Mediterranean; and from China to Southeast Asia, South Asia, and Indian Ocean. The key directions of the 21st-Century Maritime Silk Road are from Chinese coastal ports, via the South China Sea and Indian Ocean, to Europe, and from Chinese coastal ports, via the South China Sea, to the South Pacific Ocean ${ }^{3}$.

On April 7, 2013, Chinese President Xi Jinping put forward to build a regional financing platform to promote regional economic integration and improve regional competitiveness in the keynote speech of Boao Forum for Asia ${ }^{4}$. This became a preliminary conception for "the Belt and Road". Subsequently, President Xi Jingping and Premier of the State Council Li Keqiang successively proposed the ideas to build the Silk Road Economic Belt and to build the 21st-Century Maritime Silk Road in a number of different occasions, and put forward to promote the construction of the Silk Road Economic Belt and the 21st-Century Maritime Silk Road by building the Asia Infrastructure Investment Bank and so on. On March 28, 2015, National Development and Reform Commission, Ministry of Foreign Affairs, and Ministry of Commerce of China jointly issued "Vision and Actions on Jointly Building Silk Road Economic Belt and 21st-Century Maritime Silk Road”, and then "the Belt and Road" strategy was formally established as a national strategy.

It is very important to study the nature and logic of "the Belt and Road" initiative, because "the Belt and Road” Initiative involves the cooperation among many countries, and it is imperative for these countries to make an agreement about the core connotation of "the Belt and Road" Initiative so as to dispel their doubts. Understanding the reasons of putting forward "the Belt and Road" Initiative is good for finding the attractions of this initiative. Also pointing the development directions of this initiative can help all related countries to focus on the fields they may cooperate in the future. This paper is devoted to analyzing the economic nature and logic of "the Belt and Road" and clarifying how to cooperate between China and other countries.

This paper is organized as follows. Section 2 is literature review. Section 3 analyzes the domestic and international background of proposing "the Belt and Road" from a macroeconomic perspective. Section 4 proposes a basic model of understanding the economic nature of "the Belt and Road" from two different levels. Section 5 discussed the great strategic meaning of implementing "the Belt and Road" for China. Section 6 points out how to cooperate between China and European countries and between China and North American

\footnotetext{
${ }^{1}$ OECD (2013) estimated that capital contributed 59\% to China’s economic growth from 1996 to 2001, 59.1\% from 2001 to 2006, and up to 65\% from 2006 and 2011. Minjie Dong and Yongmei Liang (2013) estimated that capital contributed 85.4\% to China's economic growth from 1978 to 2010. Even though these estimations were different, but all of them showed that capital contributed more than 50\% to China's economic growth (Chow \& Lin, 2002; Wang, 2000).

2 Many economic studies show that infrastructure construction significantly promotes the economic growth and social development of developing countries (Duflo \& Pande, 2007; Kremer, Leino, Miguel, \& Zwane, 2011; Duranton \& Turner, 2012; McRae, 2015).

3 National Development and Reform Commission, Ministry of Foreign Affairs, Ministry of Commerce of China, Vision and Actions on Jointly Building Silk Road Economic Belt and 21st-Century Maritime Silk Road [N]. People’s Daily, 2015-03-29 (4).

${ }^{4} \mathrm{Xi}$ Jingping. Working together toward a better future for Asia and the world-the keynote speech at the opening plenary of the Boao Forum for Asia Annual Conference 2013. Xinhua: http://news.xinhuanet.com/politics/2013-04/07/c_115296408.htm.
} 
countries and Section 7 is conclusion.

\section{Literature Review}

“The Belt and Road” Initiative is a very new research topic in China, because of its practical value and strategic significance, and many scholars chose "the Belt and Road" as their new research interests when this initiative was put forward at the first time. For example, "the Belt and Road" brought about several new research themes in geography, including geopolitical studies, foreign direct investment theories, optimization of transcontinental transportation, and so on (Liu, 2015). For implementing this initiative, some relations should be handled first, such as government-enterprise relations, central and local authorities' relations, and so on (Li, 2015), and some questions should be answered first, as should it be based on multiple bilateral partnerships of cross-regional integration? (Chu \& Gao, 2015). Also in the process of implementing "the Belt and Road" initiative, it will face a lot of barriers, such as heavy cost in infrastructure construction and its maintenance (M.-C. He, J.-B. Zhang, Y.-F. Zhang, \& B. Tian, 2015). At the same time, "the Belt and Road” Initiative will have a great influence on the foreign investment (Yang \& Yan, 2015), and it is beneficial to upgrade the related industries of China (Dong \& Liang, 2015) and push the industrial transformation (Su, 2015). Although a lot of scholars from many aspects investigated "the Belt and Road" Initiative, but very few scholars did research about economic nature and logic of "the Belt and Road" (Huang, 2015). Answering the question why "the Belt and Road" initiative should be implemented is very important, and only other countries understand the economic nature and logic of "the Belt and Road" initiative, and they are willing to cooperate with China to implement this initiative. Therefore the topic of this paper is very meaningful and valuable.

\section{The Background of Raising “The Belt and Road” Strategy}

\section{The Recovery of World Economy Is Weak, and Emerging Markets Have Become an Important Growth Momentum}

After the financial crisis in 2008, the world economy is recovering gradually. According to World Economic Situation and Prospects $2015^{5}$, issued by the United Nations, American GDP growth rate was 2.2\% in 2013, and it would be expected to achieve $2.4 \%$ and $2.8 \%$ in 2014 and 2015. This is higher than the average GDP growth rate of developed countries (in 2013, the overall GDP growth rate of developed countries was $1.2 \%$, and the expectations were $1.6 \%$ and $2.2 \%$ in 2014 and 2015). The growth rate of countries in Euro Zone was $0 \%$ in 2013, and the expectations were 1.3\% and 1.9\% in 2014 and 2015. Overall, economies of the United States and Japan have recovered, and their growth trends are strong, while countries in Euro Zone are affected by European debt crisis and their economies are declining mildly. In contrast, the overall growth rate of developing countries maintains over $4.4 \%$ (the GDP growth rate of developing countries was $4.7 \%$ in 2013 , and the expectations were $4.4 \%$ and $4.4 \%$ in 2014 and 2015). After the financial crisis, the "two speed" pattern of developed economies and emerging economies will be further deepened. According to the forecast of the International Monetary Fund, by 2050, GDP of "BRIC countries” (China, Brazil, Russia, India, and South Africa) will exceed other large industrial countries, such as the United States, Britain, Canada, France, Germany, Italy, and Japan, and emerging markets which represented by China and the Central and West Asian countries will become the important driving force of world economic growth. Asian developing countries

5 UN DESA. World Economic Situation and Prospects: Mid-2015 Update, 2015-07, http://www.un.org/en/development/desa/policy/wesp. 
which represented by the Central and West Asian countries have a vast market. According to the estimation of the Asian Development Bank ${ }^{6}$, the annual Asian infrastructure funding needs will reach $\$ 730$ billion in the next 8 to 10 years, and the World Bank estimates that this number will be $\$ 800$ billion. But the sum of infrastructure investment in Asia from the Asian Development Bank and the World Bank is only about $\$ 30$ billion. Therefore, the financing gap of infrastructure construction in Asia is huge. Lack of funding has restricted infrastructure construction and the economic growth of developing countries and regions, which was represented by the Central and West Asian countries.

\section{New Normal of China's Economy Introduced to Initiative “the Belt and Road” Strategy}

New normal of China's economy means that China's economy entered a normal growth phase after more than 30 years of rapid growth, and the speed of economic growth will be kept around 7\%. There are plenty of important factors to promote the long-term stable growth of China's economy over the past 30 years, such as vast domestic market, comparative advantage of labor, institution reform, and urbanization. However, because labor cost rises, the process of urbanization becomes stable, and growth of investment and consumption slows down, it is urgent for China's economy to seek for a new economic growth point. In addition, since the beginning of the 21st century, redundant construction and overcapacity have influenced the development of China's economy, especially since the financial crisis in 2008. Blind investment which stimulated by the "4 trillion" investment plan, the top 10 industrial revitalization plan, and loose monetary policy, exacerbated the overcapacity problem ${ }^{7}$.

At the same time, it should be seen that in the new round of adjusting industrial structure, transformation and upgrading have become the main melody of this round, and core elements, such as market, capital, talent, and product, become the focus of adjusting industrial structure. After 30 years of technology accumulation and upgrading, China's manufacturing, especially middle-end manufacturing, has reached the middle or high-level in the world. China's economic growth needs to solve the overcapacity problem by using the comparative advantage of manufacturing to expand international market. Besides, a new pattern of China's regional development has been produced. In February, 2014, Eastern and Coastal developed area first implemented regional planning strategy, such as collaborative development strategy of Beijing, Tianjin, and Hebei, and the Yangtze River economic belt strategy. By the end of 2014, the GDP growth speed of Guangxi, Hunan, and Sichuan has exceeded the speed of eastern developed regions for successive seven years. How to achieve regional coordinated development, promote regional trade, and stimulate economic growth becomes another problem for China's economy. In recent years, China has made a lot of strategies and plans to promote regional economic integration, including the Silk Road Economic Belt strategy, the 21st-Century Maritime Silk Road strategy, BCIM (Bangladesh, China, India, and Myanmar), Economic Corridor strategy, China and Pakistan Economic Corridor strategy, the Northeast Asia economic integration strategy and so on. All of these strategies focus on regional economic integration with the basis of China's national strategies and are in line with member states' strategic interests.

\footnotetext{
${ }^{6}$ B. N. Bhattacharyay, K. Masahiro, and N. Rajat (Eds.). Infrastructure for Asian connectivity. Edward Elgar Publishing, 2012.

7 Han, G.-G., Gao, T.-M., Wang, G.-L., Qi, Y.-F., and Wang, X.-S. (2011). Research on measurement, volatility and causes of excess production capacity of Chinese manufacturing industries. Economic Research Journal, 12, 18-31.
} 


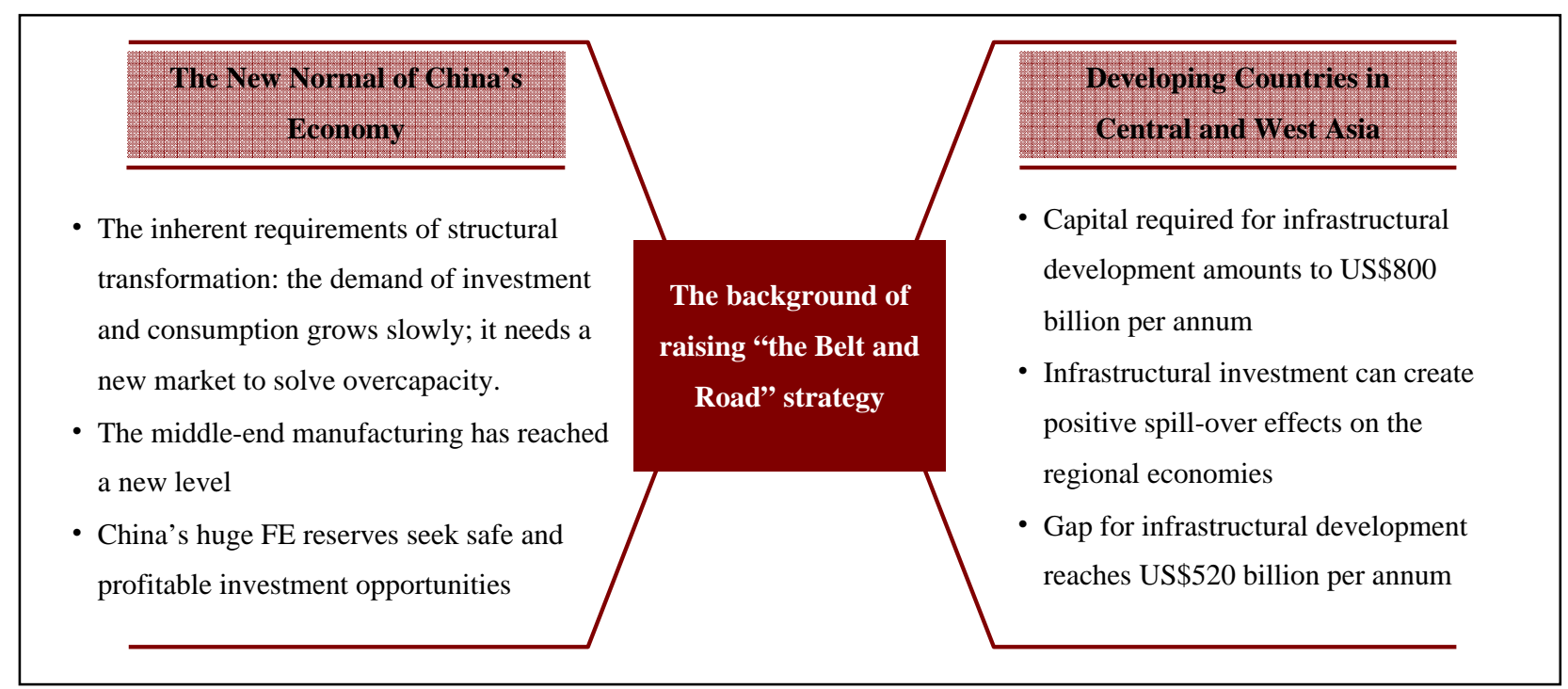

Figure 1. The background of raising "the Belt and Road” strategy.

In short, China's economy under new normal, urgent needs to transform and upgrade, and it is necessary for China to open up a new market to expand the sale channels of manufactured goods and expand foreign investment, while these Asian developing countries represented by Central and West countries are facing a huge demand of capital, manufactured goods, and technologies. So the matching of these two sides provides basic conditions to initiative "the Belt and Road" in 2013 and formally implement it in 2015.

\section{Research Methods: Basic Models of Understanding the Nature of “The Belt and Road”}

\section{A Basic Model: The Interaction and Win-Win Between China and the Central and West Asian Countries (CWA) and Southeast Asian Countries (SEA)}

Given that China has inherent demands to transfer its economic structure and expand market, China has the huge foreign exchange reserves and seeks for steady investment projects and opportunity, and other Asian countries represented by the Central Asian countries have vast domestic market, but lack of infrastructure funding, the basic model of understanding the nature of "the Belt and Road" can be built by designing an economic circular route: China facilitates its infrastructure construction projects to go out by providing low-interest loans to other countries, and promotes other countries' economic growth by these infrastructure construction, then other countries use their economic benefits to return their loans (see Figure 2).

Specifically, China provides low-interest loans to other Asian countries, and executes infrastructure construction. On the one hand, it is achieved to effectively expand international market for overcapacity and it helps China find a robust investment channel for foreign exchange reserves. China's funds mainly come from huge foreign exchange reserves, the local Silk Road Fund from these provinces along the line, and social capitals raised by the way of debt or other forms. The output infrastructure construction includes roads, railways, high-speed rail, power, and other industries. The production capacity of related fields, such as communications and construction machinery, also can be outputted. On the other hand, governments and enterprises in these developing countries which have an economic growth through infrastructure construction can pay the low-interest loans by using the revenue of tax and projects. In a word, developing countries provide broad markets, and get funds and technology for development, and when infrastructure construction is finished, 
they can use the "spillover effects" of infrastructure to promote economic development and use revenue surplus to pay loans. At last, both China and these developing countries achieve a win-win situation.

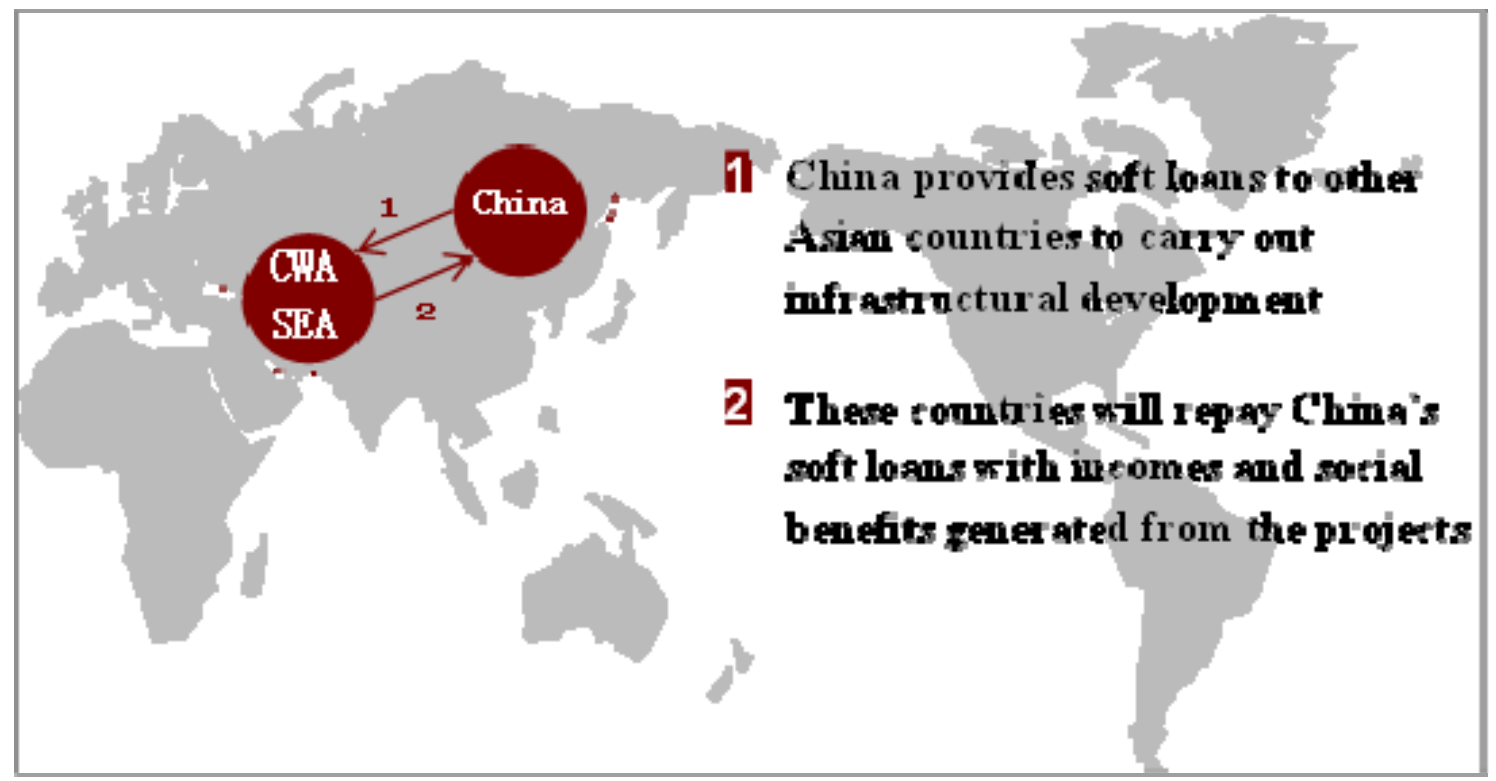

Figure 2. A basic model: the interaction and win-win between China, the Central and West Asian countries (CWA), and Southeast Asian countries (SEA).

An Extended Model: The Multilateral Win-Win Situation Between China and Other Countries in Asia,

\section{Europe, and Africa}

“The Belt and Road” strategy was born of economic interaction between China and other Asian countries. It starts from the fundamental demand and supply of bilateral market and is devoted to satisfying bilateral benefits between China and other Asian countries. In fact, the Silk Road Economic Belt connected Asia-Pacific economic circle from east side and European economic circle from west side, and it's considered as the longest and most potential economic corridor in the world. European industrial countries which face a mild recession are more likely to participate in the construction of "the Belt and Road" strategy through their technical advantages, so that they can obtain the vast markets in Central Asia countries. As the leading country of "the Belt and Road", China occupies a significant position in the basic model of "The Belt and Road". Meanwhile, cooperating with European industrial countries to invest towards developing countries is conducive to provide a platform for Chinese enterprises to learn the advanced technology and marketing experience, and help Chinese manufacturing upgrade its technology. So, European countries as the third party participating in the construction of "the Belt and Road", and achieving international cooperation in capacity came into being. African countries also need infrastructure construction. Considering these, the basic model of "the Belt and Road” strategy can be extended (see Figure 3).

As "the Belt and Road" strategy is advancing, African countries will be beneficiaries on the next stage. According to World Economic Situation and Prospects 2015, which was released by the United Nations, the GDP growth speed of African countries in 2013 was up to 3.3\%, and it was expected to reach $4.0 \%$ in 2015 and $4.8 \%$ in 2016. Among them, the GDP growth speed of Eastern African countries was up to 6.5\%, and they were expected to reach $6.6 \%$ in 2015 and $6.7 \%$ in 2016, where the growth speed of this area is far more than the speed of other countries and regions in the world. There are at least two aspects to understand why African 
countries benefit from "the Belt and Road" strategy: on the one hand, with the construction of infrastructure, some African countries will become the input market of capital and technology, and they could directly benefit from these infrastructure construction; on the other hand, the regional development driven by the Central Asian countries' infrastructure construction will benefit African developing countries. The regional factor flow is in favor of the regional coordinated development.

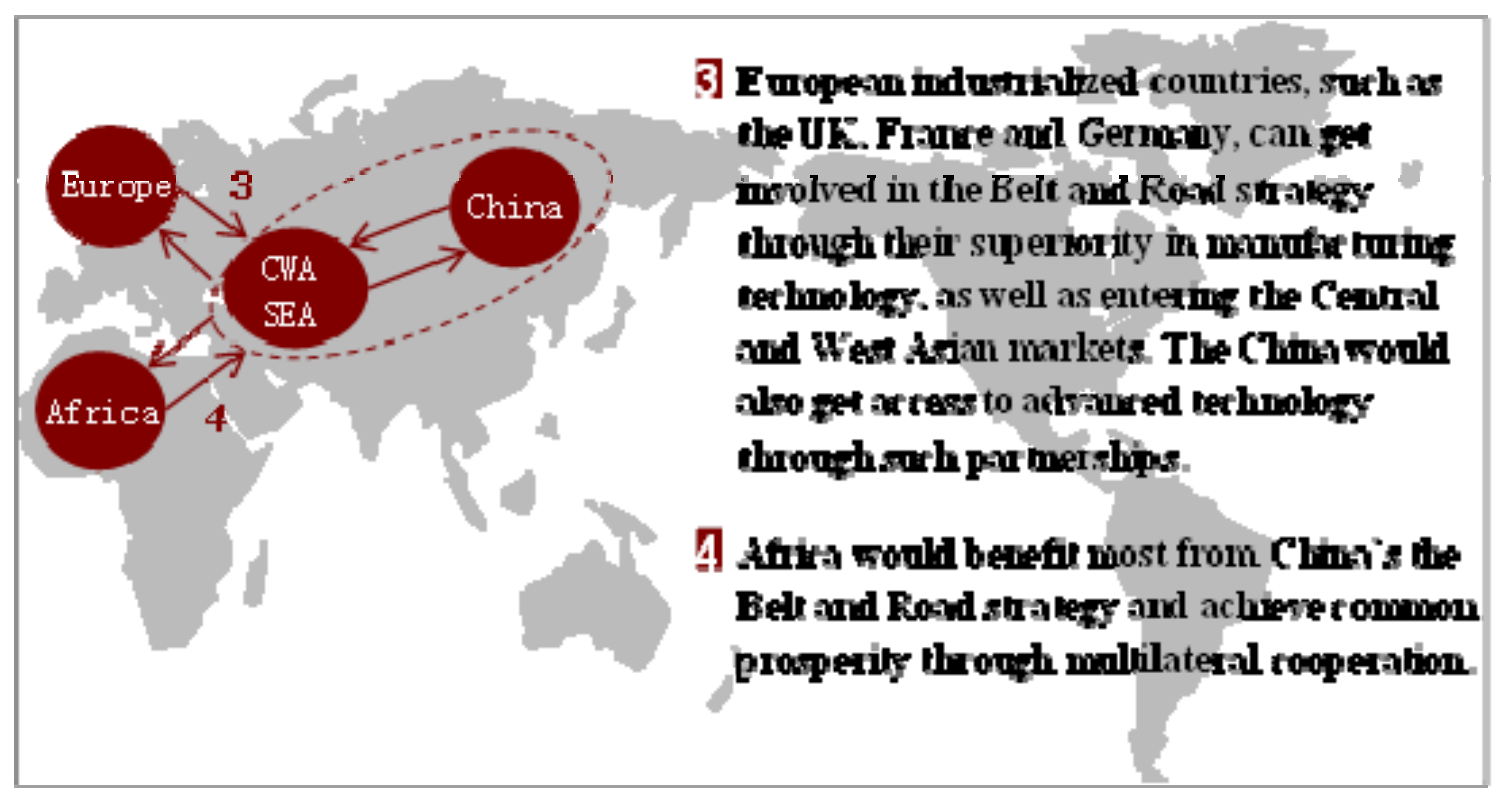

Figure 3. An extended model: the multilateral win-win situation between China and other countries in Asia, Europe, and Africa.

In recent years, the major European countries have improved their attitudes to China after raising "the Belt and Road" initiative, to a great extent, which not only certifies that "the Belt and Road" is very attractive to European countries, but also proves the logic of "the Belt and Road" idea is self-consistent. The active participation of European and African countries greatly expands and enriches the connotation of "the Belt and Road” strategy.

Put the Figure 2 and Figure 3 together, considering that it is possible for the North American countries to join in the future, another extended model including the North American countries was established, and that is the comprehensive theoretical model of "the Belt and Road" strategy (see Figure 4 ).

The theoretical model of "the Belt and Road" is based on the development status quo of China's and other countries' economies and macro background of international economy. It abstractly simplifies member countries as market entities and analyzes the behaviors and benefits of all participating parties from the perspective of supply and demand. It tries to prove that the logic of "the Belt and Road" is self-consistent. Finally, it deserves to notice that it is unnecessary for theoretical model to include all the contents of "the Belt and Road", but it really is an ideological weapon to help us understand the economic nature of "the Belt and Road”. 


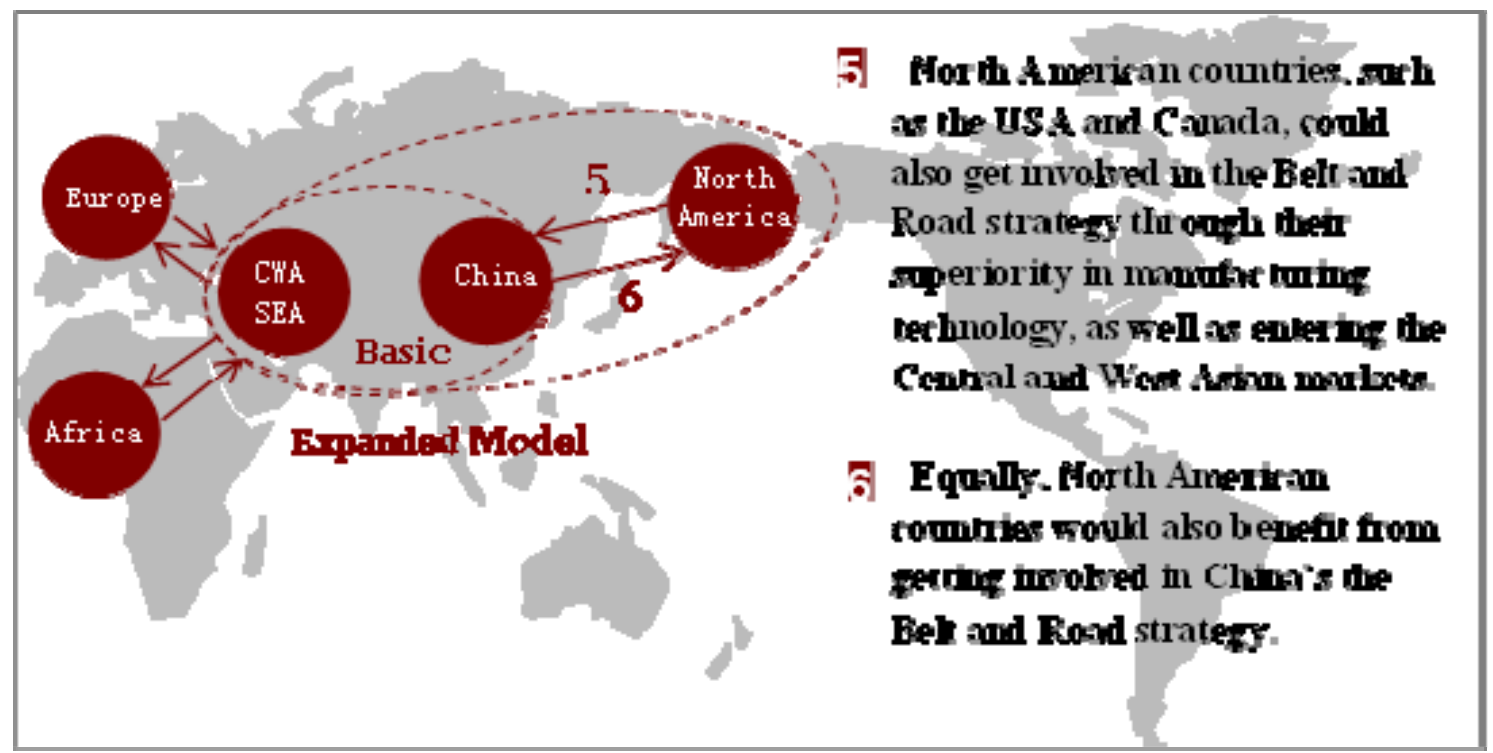

Figure 4. The comprehensive theoretical model of "the Belt and Road" strategy: the multilateral win-win situation including all member countries.

\section{The Significance of the Implementation of "The Belt and Road" Strategy to China's Development}

As a medium- and long-term national strategy, "the Belt and Road" initiative is mainly to solve several important problems which are related to the development in the future, such as to create a new driving force of economic growth, to develop a new pattern of opening-up, to deepen national strategies, to strengthen national security, to grasp the leadership of regional economy, to promote the reform of the global governance structure and so on. This is of great significance to the stable development after China's economy enters into a new normal.

\section{To Create a New Driving Force of Economic Growth}

Overcapacity becomes a serious problem for economic operation. Traditional countries that China exports to are narrow, and among them, the United States, Japan, and European countries occupied the core position. China's traditional export market has relative fully developed, and plus the economic growth of the United States, Japan, European countries are weak, there is little room for expanding export market in these countries, so it is difficult for these countries to digest China's overcapacity. In the case that domestic consumption is hardly accelerated, expanding new export market through "the Belt and Road" is a realistic choice matched with China's economic growth.

In addition, maintaining and increasing the value of foreign change assets are another big problem for China at present. Due to the fund gap of infrastructure construction which exists in emerging countries and less developed countries, China can use its foreign exchange reserve to invest overseas infrastructure construction to stimulate global economic growth and digest its overcapacity by capital export. Therefore, "the Belt and Road” strategy creates a new driving force of China's economic growth.

\section{To Develop a New Pattern of Opening-up}

In the 38 years since reform and opening-up, China has made remarkable achievements. But affected by geographical location, nature resources, development foundation, and other factors, the pattern of China's 
opening-up generally presents that the east areas are faster than the west areas, and the coastal areas are faster than the inland areas. The implementation of "the Belt and Road" strategy will help to build "one body with two wings" of new round opening-up, which is advancing the opening-up of the west regions and the inland areas. Following the Silk Road spirit which is peaceful cooperation, openness, inclusiveness, mutual learning, mutual benefit, and win-win, China carries out "the Belt and Road" strategy, and cooperates with those countries along the line in aspects of infrastructure construction, trade and investment, energy, regional integration, internationalization of RMB, etc. This would develop a new pattern for China's opening-up.

\section{To Deepen National Strategies and Strengthen National Security}

At present, China imports resources mainly through the coastal sea-lane, but sea route is directly exposed to external threats, and it is extremely fragile during the war. China's industries and infrastructure are also concentrated in the coastal regions. So if these regions are attacked, China will lose core infrastructure. In central and west areas, especially the west areas, there are few people in wild land, the potential of developing industry and infrastructure is great and the threats during the war are less. Exploiting the west areas via "the Belt and Road” strategy is beneficial to deepen national strategies and enhance national security.

To Grasp the Leadership of Regional Economy and Promote the Reform of the Global Governance Structure

For China, "the Belt and Road” strategy is not only against the TPP (Trans-Pacific Partnership Agreement) and TTIP (Trans-Atlantic Trade and Investment Partnership) which are led by the United States excluding China, but also gives China the opportunity to gain rights to make new global trade rules in the economic activities of "The Belt and Road". For example, the 21st-Century Maritime Silk Road will be constructed based on domestic and overseas ports and impels negotiations of various free-trade agreements. After the successful test of Shanghai free-trade zone, China can build an international transshipment port which relies on the deep-water ports of Shanghai (including Ningbo-Zhoushan) and Quanzhou, and makes it become the international center of economy, finance, trade, and shipment, so that China can obtain the leadership of international trade, pricing, and resource allocation. In a word, China can greatly enhance its regional economic influences through accelerating the regional economic integration.

\section{The Significances of "the Belt and Road" Strategy to the Cooperation Between China and European Countries and the Cooperation Between China and North American Countries}

\section{The Significance of "The Belt and Road" Strategy to the Cooperation Between China and European Countries}

There is a long history of trade for China and European countries. For European countries which are looking forward to revival and transformation of economy and China which is trying to go out, they are indispensable partners for each other in this new stage of economic growth. In 2015, the value of trade between China and European Union (EU) amounted to $€ 521$ billion, and it accounted for 15\% of total EU's trade value. EU is keeping the largest trade partner to China for consecutive 11 years, and China is also the second largest trade partner to EU. In the same year, the actual investment from EU to China is \$7.11 billion, and its growth speed is $11.9 \%$. The direct investment from China to EU is $\$ 23$ billion, and its growth speed is $21.7 \%$. The scale and growth speed of trade and investment reflect the close economic relations and common interests of China and European countries. "The Belt and Road" construction is a new opportunity to expand the depth and 
breadth of cooperation between China and European countries and from the starting point and the end of "the Belt and Road", China and European countries will be further integrated in the aspect of economy.

Specifically, "the Belt and Road" construction will promote economic cooperation between China and European countries in the following aspects: First, infrastructure construction is conducive to achieve connectivity between two sides. The investment of infrastructure construction is the core of "the Belt and Road” strategy, and increasing trade value and insufficient shipping also confirm the necessity of transportation construction. The construction of the Maritime Silk Road shortens the distance of shipping and reduces the cost of transportation, and the construction of overland railway creates the new investment opportunities and leads to the development of regional economy. Cooperation in infrastructure construction which is good for achieving the connectivity of Eurasia is the cornerstone of economic integration between China and European countries in the future. Second, the connection of strategic planning promotes the growth of investment and trade between China and European countries. "The Belt and Road" strategy corresponds to a number of European planning. For example, at the end of 2014, The EU launched the European Strategic Investment Plan (Juncker plan) which focuses on stimulating European economy, but it has a large funding gap. Connecting this plan with "The Belt and Road" strategy can not only get the funds, but also strengthen bilateral cooperation in investment and trade. Third, the financial services ensure the smooth operation of real economy. In recent years, the speed of RMB internationalization is accelerated, and the cooperation between China and European countries in the field of monetary and finance also steps up to a new level. European countries have actively joined the Asian Infrastructure Investment Bank, which shows that China and European countries are committed to building a two-way investment channels. A deep-level economic cooperation is conducive to the development of real economy. Finally, "The Belt and Road" strategy is in favor of carrying out all-round cooperation in the economic field. The construction of "digital Silk Road" will lead the bilateral economic cooperation from the traditional fields to emerging fields, such as internet and communication, and information technology cooperation is beneficial for e-commerce, internet finance, and other industries to rise sharply. The successful experience of European urbanization is worth learning by China, so establishing the friendship between cities is good for the cooperation in city's facilities construction and so on. China has large energy consumption with low utilization rate, and its energy structure is single while European countries have high dependence on foreign energy, so both of them have some problems of energy. "The Belt and Road" strategy gives the opportunity to cooperate in the aspect of energy.

"The Belt and Road" construction makes a huge room for China and European countries to cooperate and the prospect is bright. However, advancing "the Belt and Road" construction is not without any frictions, trade disputes between China and European countries, political mutual trust and coordinating interests with other countries, such as Russia and the United States, all of which are challenges of the cooperation between China and European countries. Under the framework of "the Belt and Road" strategy, how to control differences and achieve fruitful cooperation depend on the strategic wisdom of China and European countries.

\section{The Significance of “The Belt and Road" Strategy to the Cooperation Between China and North American Countries}

As early as 2011, the United States put forward the strategy of "new Silk Road”, and invested the Central and South Asia based on the bilateral relations. Despite profound differences between "the Belt and Road" strategy raised by China and "the new Silk Road" strategy raised by the United States, "the Belt and Road" 
strategy involves a large number of economic projects and a vast market, especially in the process of promoting the implementation of this strategy in the Central Asia, West Asia, and Middle East. The United States and China have a lot of common interests and broad space for cooperation. China's initiative of infrastructure construction is helpful for America to execute its planning in these areas, and America has a great advantage of transportation construction, environment management, marine exploitation and management which can be played very well under the framework of "the Belt and Road" strategy. Sino-US enterprises have many opportunities to cooperate in these aspects of ports, roads, transportation facilities, finance, energy etc. Under the framework of "the Belt and Road" strategy, China and the United States do not play a zero-sum game, and they need to have greater political trust so as to promote economic cooperation between two countries in a deeper level. On May 9, 2016, British Columbia and Guangdong province signed cooperation documents of mutual support, participating in "the Belt and Road" strategy and "Pacific Gateway Strategy". It marked that "the Belt and Road" strategy extended to the North America for the first time. China is the second largest trade partner of Canada, and Canadian companies have advantages in many aspects of infrastructure construction and project management. Canadian enterprises can join the economic development in these countries along the line of "the Belt and Road" to achieve a win-win situation with China. In 2015, the first offshore RMB clearing center was launched in Toronto, Canada, and the financial integration between China and Canada saves a lot of trade costs. Canada can also use the capital advantage of RMB to actively join in "the Belt and Road" construction in the future. Although current "the Belt and Road" strategy doesn't cover the area of North America geographically, this strategy is inclusive enough. The North American countries can play an important role in the implementation of this strategy by using their comparative advantages.

Implementing “the Belt and Road” strategy is not only an inevitable logic of China's all-round opening-up and an certain trend of civilization renaissance, but also a necessary requirement of inclusive development of globalization. It faces new opportunities in aspects of all-round opening-up, diplomacy, cooperation, and global development, and also faces various risks, such as geopolitics, security, economy, and market. Therefore, the study on this topic is definitely different from other studies, and it has several characteristics: comprehensive, strategic, systematic, international, and long-term. Now, analyzing these specific issues in depth is particularly important, and this paper is an attempt in this respect.

\section{Conclusions}

The Silk Road Economic Belt links Asia Pacific in the east with European in the west, which is regarded as the world's longest economic corridor with a huge development potential, and the 21th-Century Marine Silk Road is intended to strengthen China's economic links with ASEAN countries. These two parts constitute the core of "the Belt and Road" Initiative. "The Belt and Road" Initiative is strategic. On one hand, it meets the requirements of structural transformation and seeks for profitable investment opportunities of China, and on the other hand, it meets the requirements of infrastructural development of Central and West Asian countries. So there is a big room for China and these developing countries to improve the cooperation. For example, China can provide the soft loans to other Asian countries to carry out infrastructure development and then these countries will repay China's soft loans with incomes and social benefits generated from the projects. Except for the cooperation between China, Central and West Asian, and Africa countries, it is possible and important to strengthen the cooperation between China, European, and North American countries. Industrialized countries, such as UK, USA and so on, can get involved in the initiative through their superiority in manufacturing 
technology. In conclusion, “the Belt and Road” Initiative is a multilateral win-win development strategy which has a broad prospect, so more and more countries should be involved in.

\section{References}

Chu, Y., \& Gao, Y. (2015). China’s Belt and Road Initiative: Three questions to be answered. International Economic Review, 2, 90-99.

Dong, M.-J., \& Liang, Y.-M. (2013). The source of China’s economic growth from 1978 to 2010: A non-parameter framework. Economic Research Journal, 5, 17-32.

He, M.-C., Zhang, J.-B., Zhang, Y.-F., \& Tian, B. (2015). Strategy of “one Belt and one Road” confronted with barriers and countermeasures. Journal of Xinjiang Normal University (Philosophy and Social Sciences), 36(3), 36-45.

Huang, H.-T. (2015).. “The Belt and Road” Initiative: The nature of interaction and the building of trust. Tianjin Social Sciences, 6, 87-92.

Liu, W.-D. (2015). Scientific understanding of the Belt and Road Initiative of China and related research themes. Progress in Geography, 34(5), 538-544.

Li, X.-Y. (2015). Relations to be prioritized in China’s “Belt and Road Initiative”. International Economic Review, 1 , 54-63.

Su, H. (2015). A study on the transfer of China's manufacturing under “the Belt and Road” Initiative. International Trade, 3, $18-21$.

Yang, F.-H., \& Yan, C.-F. (2015). A study on the implementation mechanism of Chinese direct investment under "the Belt and Road” Initiative. Theoretical Investigation, 5, 80-83. 